\title{
LIGHTWEIGHT CONCRETE WITH MIXED FOAM AGENT, POLYMER AND BONDING TO REACH $300 \mathrm{Kg} / \mathrm{Cm}^{2}$
}

\author{
Siti Rukmayani Japar, \\ sitirukmayani@gmail.com, \\ Engineering Faculty \\ Civil Engineering Study Program \\ Narotama University Surabaya, Jl. Arif Rahman Hakim 51 Surabaya \\ Fredy Kurniawan \\ Engineering Faculty \\ Civil Engineering Study Program \\ Narotama University Surabaya, Jl. Arif Rahman Hakim 51 Surabaya \\ fredy@narotama.ac.id
}

\begin{abstract}
Lightweight concrete is very much developed because of its benefits that can reduce the weight of the building itself, so that the earthquake effect on buildings can be minimized. By using Foam Agent Technology, it will add air pores which can reduce the specific gravity of normal concrete. To achieve the K 300 Concrete Quality with Light Weight, the researchers added Polymer and Polymer and Bonding mixture to the Concrete mixture using Foam Agent technology. From the research conducted by researchers, it was found that Foam Agent is able to help concrete become lighter by $13 \%$. This research was also able to obtain the optimum compressive strength results with a light weight, the Light Concrete study with the addition of Foam Agent, Polymer and Bonding with a quality of $267 \mathrm{~kg} / \mathrm{cm}^{2}$ or equivalent to $\mathrm{Fc} 22$ with a weight of $1877 \mathrm{Kg} \mathrm{/} \mathrm{cm}{ }^{3}$ and an efficiency coefficient of $14 \%$ which is higher than normal Concrete $\mathrm{K} 300$ with a magnitude of $13 \%$.
\end{abstract}

Keywords: Lightweight concrete, High Strenght, Foam Agent, Polymer, Bonding,

\section{INTRODUCTION}

Until now, concrete is still the main choice in making structures. Apart from the ease of obtaining its constituent materials, it is also caused by the use of large enough labor so as to reduce the problem of providing employment. In addition to the two main performances mentioned above, namely high compressive strength and ease of processing, the continuity of the concrete procurement process in the production process is also one of the things to consider. The properties and characteristics of the constituent concrete material will affect the performance of the concrete made.

Based on the types of concrete, it can be divided into three, namely concrete based on its weight, concrete based on its forming material and the use of its structure, and concrete based on its volume weight. Concrete type based on its weight can be divided into three namely heavy concrete, medium concrete and lightweight concrete. Likewise Concrete Types based on their volume can be divided into three, namely heavy, light and normal.

Research on concrete continues to grow along with the times and technology. One of them is research on lightweight concrete. Lightweight concrete is very much developed because of its benefits that can reduce the weight of a building itself, so that the earthquake effect on buildings can be minimized. This is caused by the compressive strength of lightweight concrete which is quite high but has a low fill weight. The main elements of lightweight concrete are aggregates in the form of lightweight aggregates. 
Based on this background, the problems to be examined are:

1) How to find concrete that can produce lightweight concrete with a quality of up to $\mathrm{K} 300$ ?

2) What is the result of the reaction Addition of Polymer and Foam Agent on Concrete Quality?

3) What is the result of the addition of Bonding, Polymer and Foam Agent reactions to Concrete Quality?

Concrete is a composite material consisting of coarse and fine aggregates mixed with water and cement as a binder and filler between fine and coarse aggregates and sometimes additives or admixture when needed. Until now, concrete is still the main choice in making structures.

Cement is a compound that is chemically active after contact with water. The aggregate does not play an important role in the chemical reaction, but serves as a mineral filler which can prevent changes in the volume of the concrete after stirring is complete and improves the durability of the resulting concrete. In general, concrete contains about $1 \%$ $-2 \%$ air cavity, cement paste (cement and water) around $25 \%-40 \%$, and aggregate (fine and coarse aggregate) around 60\% -75\%. To get good strength, the nature and characteristics of each of the constituent materials need to be studied (Mulyono, Tri. 2003).

Basically the composition of concrete can be defined by the Water Cement Ratio (WCR), the type of cement, the type of aggregate and the content of cement and aggregate. WCR is an important indicator in the design of concrete mixtures. WCR is the weight of water divided by the weight of cement. It is generally known that the higher the WCR value, the lower the quality of the concrete strength. A low WCR causes the water between the cement parts to be small and the gap between the beads of cement to be short. As a result, the mass of cement shows more relation (initial strength is more influential). In the book Concrete Technology by Tri Mulyono, said that Duff and Abrams (1919) examined the relationship between the WCR with the strength of concrete at 28 days with a cylinder test. If the WCR gets bigger, the compressive strength will decrease.

According to ASTM C.618 (ASTM, 1995: 304) Fly Ash is defined as fine grains resulting from the combustion of coal or coal powder residues. Fly Ash can be divided into two, namely normal fly ash produced from combustion of anthracite coal or bitomius coal and class $\mathrm{C}$ fly ash produced from lignite or subbitumeus coal.

Water is needed in the manufacture of concrete to trigger the chemical process of cement, soaking aggregates and providing ease in concrete work. Drinkable water can generally be used as a concrete mixture. Water containing dangerous compounds, which are contaminated with salt, oil and sugar, or other chemicals, when used in concrete mixtures will reduce the Strenght of concrete, and can even change the properties of the resulting concrete. Water that can be used for concrete mixes must be clean, must not contain oil, acids, alkalis, organic substances or other materials that can damage the concrete or reinforcement.

Normal concrete is a relatively heavy building material with a specific gravity of $2400 \mathrm{~kg}$ $/ \mathrm{m}^{3}$. The aggregate content in concrete mixes is usually very high. Based on experience, the aggregate composition ranges from $60 \%-70 \%$ of the weight of the concrete mixture (Mulyono, Tri. 2003). Although its function is only as a filler, but because of its relatively large composition, even this aggregate becomes important. Because it is necessary to study the characteristics of the aggregate which will determine the nature of the mortar 
or concrete to be produced. Aggregates used in concrete mixtures can be natural aggregates or artificial aggregates.

Admixture is material that is added to the concrete mixture at a time or during mixing. The function of this material is to change the properties of concrete to make it more suitable for certain jobs, or to save costs. Admixture or added material is defined in the Standard Defenitions of Terminology Relating to Concrete and Concrete Aggregates (ASTM C.125-1995: 61) and in Cement and concrete Terminolgy (ACI SP-19) as materials other than water, aggregates and hydraulic cements mixed in concrete or mortar added before or during stirring takes place. According to the $\mathrm{ACl}$ Committee 212.1R-81 (Resived 1986) which has always been improved since 1944, 2954, 1963, 1971, the types of added materials for concrete are grouped into five groups: Accelerating, water-entraining, water reducer and set-controling, finely devide minerals and miscellaneous. In general, added ingredients used in concrete can be divided into two, namely chemical additives (chemical admixture) and mineral additives (additives). Admixture added ingredients are added when stirring and / or when casting (while placing) while additive additives namely mineral ones are added when stirring is carried out. Whereas mineral added material is added material intended to improve concrete performance. At this time, this mineral added material is more widely used to improve concrete compressive performance, so this mineral added material tends to be cemented. Some of these added minerals are pozzollan, fly ash, slag and silica fume.

Other added ingredients are also diverse such as Air Entraining, Polymer, Hardener Concrete, Water Proofing, Dyes, and Bonding Agent for Concrete. Polymer is a new added product that can produce high strength concrete. High strength concrete is usually produced using Polymers by modifying the properties of concrete by reducing water in the field or saturating it and emitting it at very high temperatures in the laboratory.

The pouring of fresh concrete on the surface of old concrete often has difficulty in binding. To overcome this, it is necessary to add an added material so that there is a bond that joins the old surface with the new surface. The type of added material is usually called a Bonding Agent which is a Polymer solution.

Concrete based on its weight can be divided into three namely, heavy concrete, medium concrete and lightweight concrete. In this case light aggregate is a material with a weight of $1120 \mathrm{~kg} / \mathrm{m}^{3}$ for fine aggregate and $800 \mathrm{~kg} / \mathrm{m}^{3}$ for coarse aggregate. The specific gravity of lightweight concrete is around $1900 \mathrm{~kg} / \mathrm{m}^{3}$ (Mulyono, Tri. 2003).

Concrete based on quality can be divided into Low Quality Concrete, Medium Quality Concrete and High Quality Concrete. What High Quality Concrete says is concrete with Fc '<20 MPa, Medium Quality Concrete is concrete with Fc' 21-40 MPa and Low Quality Concrete is concrete with $\mathrm{FC}$ '> $41 \mathrm{MPa}$ (SNI 03-6468-2000, ACI 318, ACI 363R-92).

\section{RESEARCH METHOD}

\section{Types of research}

This type of research is a pure type of experiment with quantitative data collection methods. Pure experimental research is research that aims to examine the effect of a variable on other variables. This research method is different from other research methods, in this research method is controlled by the research variables and the treatment of the experimental group. In this study the researchers also tested both the experiment and the hypothesis of the causal relationship. 


\section{Place and time of research}

The research was conducted at the Central Laboratory of PT. Varia Concrete Business for 10 months.

\section{Overview and Data Sources}

This research will be conducted at the Central Laboratory of PT. Concrete Varia Enterprises. This research uses OPC Type I brand Semen Gresik, Fly Ash from Paiton, fine aggregate from Lumajang, and Admixture in the form of Foam Agent, Polymer and Bonding. Concrete samples or Test Objects are printed with $15 \times 30 \mathrm{~cm}$ cylindrical molds with a total of six Test Objects for each Trial Mix. Test specimens are carried out wrapped in plastic and tested at 7, 14 and 28 days with two specimens each. All data in this study are the results of the Trial Mix obtained by the author, so there is no data manipulation.

\section{Data analysis technique}

1. Collection of data, theories that are used as a reference

2. Testing of materials to be used

3. Planning the Mix Design and making Job Mix

4. Implementation of Concrete Trial and making sample specimens

5. Do a concrete compressive strength test

\section{RESULTS AND DISCUSSION}

Concrete mixtures are designed to study the effect of adding Foam Agent to the weight of concrete and the effect of compressive strength obtained from the addition of Polymer and the combination of Polymer and Bonding as shown in table 1.

Table 1. Mixing Proportion

\begin{tabular}{lcccccccc}
\hline Mix Type & $\begin{array}{l}\text { Water } \\
(\mathrm{Kg})\end{array}$ & $\begin{array}{l}\text { Cement } \\
(\mathrm{Kg})\end{array}$ & $\begin{array}{l}\text { Fly } \\
\mathrm{Ash} \\
(\mathrm{kg})\end{array}$ & $\begin{array}{l}\text { Sand } \\
(\mathrm{Kg})\end{array}$ & $\begin{array}{l}\text { Split } \\
5-10 \\
\mathrm{~mm} \\
(\mathrm{Kg})\end{array}$ & $\begin{array}{l}\text { Split } \\
10-20 \\
\mathrm{~mm} \\
(\mathrm{Kg})\end{array}$ & $\begin{array}{l}\text { Polymer } \\
(\mathrm{Ltr})\end{array}$ & $\begin{array}{l}\text { Bonding } \\
(\mathrm{Ltr})\end{array}$ \\
\hline $\begin{array}{l}\text { Normal } \\
\text { Concrete }\end{array}$ & 205 & 365 & - & 670 & 471 & 670 & - & - \\
$\begin{array}{l}\text { Mortar } \\
\text { without }\end{array}$ & 228 & 350 & 105 & 1184 & - & - & - & - \\
$\begin{array}{l}\text { Foam Agent } \\
\text { LC with }\end{array}$ & 228 & 350 & 105 & 1184 & - & - & - & - \\
$\begin{array}{l}\text { Foam Agent } \\
\text { LC with }\end{array}$ & 228 & & & & & & & \\
$\begin{array}{l}\text { Foam Agent } \\
\text { and }\end{array}$ & 159 & 350 & 105 & 1248 & - & - & 3,19 & - \\
$\begin{array}{l}\text { Polymer } \\
\text { LC with }\end{array}$ & & & & & & & & \\
$\begin{array}{l}\text { Foam } \\
\text { Agent, }\end{array}$ & 137 & 350 & 105 & 1270 & - & - & 3,19 & 3,19 \\
$\begin{array}{l}\text { Polymer } \\
\text { and } \\
\text { Bonding }\end{array}$ & & & & & & & & \\
\hline
\end{tabular}

The first trial that the researchers did was the K300 Normal Strenght Concrete Mix Trial as a reference which was considered to be the benchmark of the minimum High 
Strenght category. Then proceed with the Mix Mortar Trial (eliminating coarse aggregates in the previous Mix Design and without Admixture) as a comparison with further research. Followed by a Mortal Mix Trial with the addition of Foam Agent, to determine the effect of the additional Foam Agent used. Next Trial Mix Mortar with additional Foam Agent and Polymer. And finally the Mortal Mix Trial with the addition of Foam Agent, Polymer and Bonding. Concrete samples or Test Objects are printed with $15 \times 30 \mathrm{~cm}$ cylindrical molds with a total of six Test Objects for each Trial Mix. Test specimens are carried out wrapped in plastic (ASTM C 171) and tested at 7, 14 and 28 days with two specimens each.

Foam material is Foam Agent and Water. To make foam, the liquid foam and water are mixed using a foam generator and compressor. By using Foam Agent Technology, it will add air pores that can reduce the specific gravity of normal concrete. The results of research on the effect of adding Foam Agent on the specific gravity of concrete as shown in table 2.

Table 2. Density of each study

\begin{tabular}{ccc}
\hline Mix Type & Density $\mathrm{g} / \mathrm{cm}^{3}$ & $\begin{array}{c}\text { Efficiency Coefficient } \\
(\%)\end{array}$ \\
\hline Normal Concrete & 2377 & 13 \\
Mortar without Foam Agent & 2196 & 10 \\
LC with Foam Agent & 1906 & 9 \\
LC with Foam Agent and & 1934 & 14 \\
$\quad$ Polymer & 1877 & 14 \\
LC with Foam Agent, & & \\
Polymer and Bonding & &
\end{tabular}

Concrete based on its weight can be divided into three namely, heavy concrete, medium concrete and lightweight concrete. Heavy concrete is concrete with a specific gravity of $>2500 \mathrm{~kg} / \mathrm{m}^{3}$. For normal or medium weight concrete, it is in the range of $2,200 \mathrm{~kg} / \mathrm{m}^{3}-2,500 \mathrm{~kg} / \mathrm{m}^{3}$. While the specific gravity of lightweight concrete is around $\leq 1900 \mathrm{~kg} / \mathrm{m}^{3}$ (Mulyono, Tri. 2003).

The results of compressive strength for concrete mix at 7 days with data conversion at 28 days are shown in table 3 . The compressive strength results for concrete mix at 14 days with conversion data at 28 days are shown in table 4 . The results of compressive strength for concrete mix at 28 days days with percentage difference data from 7 day and 14 day conversion results are shown in table 5 . This study makes the normal concrete $\mathrm{K} 300$ as a reference for the compressive strength to be achieved. In this study the optimal compressive strength results were obtained at $267 \mathrm{~kg} \mathrm{/} \mathrm{cm}{ }^{2}$ or equivalent to Fc 22.

Table 3. Compressive strength of concrete for 7 days and conversion at 28 days

\begin{tabular}{lccc}
\hline \multicolumn{1}{c}{ Mix Type } & $\begin{array}{c}\text { Sample } \\
\text { Name }\end{array}$ & $\begin{array}{c}\text { Compressive } \\
\text { strength }\left(\mathrm{Kg} / \mathrm{cm}^{2}\right) \\
7 \text { day }\end{array}$ & $\begin{array}{c}\text { Compressive } \\
\text { strength }\left(\mathrm{Kg} / \mathrm{cm}^{2}\right) \\
\text { 28 day conversion }\end{array}$ \\
\hline Normal Concrete & Sampel 1 & 222 & 318 \\
Mortar without Foam & Sampel 2 & 219 & 313 \\
Agent & Sampel 1 & 197 & 282 \\
LC with Foam Agent & Sampel 2 & 158 & 226 \\
& Sampel 1 & 89 & 127 \\
& Sampel 2 & 136 & 194 \\
\hline
\end{tabular}




\begin{tabular}{llll}
\hline LC with Foam Agent & Sampel 1 & 215 & 308 \\
and Polymer & Sampel 2 & 215 & 308 \\
LC with Foam Agent, & Sampel 1 & 126 & 180 \\
Polymer and Bonding & Sampel 2 & 162 & 232 \\
\hline
\end{tabular}

Table 4. Compressive strength of concrete for 14 days and conversion at 28 days

\begin{tabular}{|l|c|c|c|}
\hline \multicolumn{1}{|c|}{ Mix Type } & $\begin{array}{c}\text { Sample } \\
\text { Name }\end{array}$ & $\begin{array}{c}\text { Compressive } \\
\text { strength }\left(\mathrm{Kg} / \mathrm{cm}^{2}\right) \\
14 \text { day }\end{array}$ & $\begin{array}{c}\text { Compressive } \\
\text { strength }\left(\mathrm{Kg} / \mathrm{cm}^{2}\right) \\
28 \text { day conversion }\end{array}$ \\
\hline \multirow{2}{*}{ Normal Concrete } & Sampel 1 & 264 & 300 \\
\cline { 2 - 4 } $\begin{array}{l}\text { Mortar without Foam } \\
\text { Agent }\end{array}$ & Sampel 2 & 268 & 304 \\
\hline \multirow{2}{*}{ LC with Foam Agent } & Sampel 1 & 153 & 174 \\
\cline { 2 - 4 } & Sampel 2 & 253 & 288 \\
\cline { 2 - 4 } $\begin{array}{l}\text { LC with Foam Agent } \\
\text { and Polymer }\end{array}$ & Sampel 1 & 137 & 156 \\
\hline LC with Foam Agent, \\
Polymer and Bonding & Sampel 1 & 129 & 257 \\
\cline { 2 - 4 } & Sampel 2 & 227 & 248 \\
\cline { 2 - 4 } & Sampel 1 & 218 & 270 \\
\hline
\end{tabular}

Table 5. Compressive strength of concrete for 28 days and percentage difference data from 7 day and 14 day conversion results

\begin{tabular}{lcccc}
\hline \multicolumn{1}{c}{ Mix Type } & $\begin{array}{c}\text { Sample } \\
\text { Name }\end{array}$ & $\begin{array}{c}\text { Compressive } \\
\text { strength }\left(\mathrm{Kg} / \mathrm{cm}^{2}\right) \\
28 \text { day }\end{array}$ & $\begin{array}{c}\text { Difference in } \\
\text { Compressive } \\
\text { Strength of } 7 \\
\text { days - 28 } \\
\text { days (\%) }\end{array}$ & $\begin{array}{c}\text { Difference in } \\
\text { Compressive } \\
\text { Strength of } \\
\text { 14 days - 28 } \\
\text { days (\%) }\end{array}$ \\
\hline Normal Concrete & Sampel 1 & 306 & 4 & -2 \\
Mortar without & Sampel 2 & 304 & 3 & 0 \\
Foam Agent & Sampel 1 & 247 & 12 & -42 \\
LC with Foam & Sampel 2 & 177 & 22 & 39 \\
Agent & Sampel 1 & 165 & -30 & -6 \\
LC with Foam & Sampel 2 & 163 & 16 & -11 \\
Agent and Polymer & Sampel 1 & 279 & 9 & -9 \\
LC with Foam & Sampel 2 & 245 & 21 & 1 \\
Agent, Polymer and & Sampel 1 & 275 & -53 & -2 \\
Bonding & Sampel 2 & 260 & -12 & -28 \\
\hline
\end{tabular}

If at the base the higher the quality of the concrete, the higher the weight of the concrete will be. However, in this study the optimum compressive strength with light weight was obtained in the study of lightweight concrete with the addition of Foam Agent, Polymer and Bonding with a quality of $267 \mathrm{~kg} / \mathrm{cm}^{2}$ or equivalent to Fc 22 with a weight of $1877 \mathrm{~kg} / \mathrm{cm}^{3}$ and an efficiency coefficient of $14 \%$ which which is higher than normal Concrete $\mathrm{K} 300$ with a magnitude of $13 \%$. 


\section{RESULT AND DISCUSSION}

This research has succeeded in getting the effect of adding Foam Agent which is able to make the specific gravity of the concrete lighter, but this research cannot yet be said to have succeeded in reaching Concrete quality K 300 . Strength. The effect of using Foam Agent on Concrete specific gravity, it was found that concrete with Foam Agent mixture has a lighter density of $13 \%$. Judging from the Concrete Compressive Strength, the optimum Compressive Strength reaches Strength of $267 \mathrm{~kg} / \mathrm{cm}^{2}$ or equivalent to Fc 22. Effect of Polymer Addition on Concrete Compressive Strength, it is found that Lightweight Concrete with the addition of Polymer mixture can increase Concrete Strength by up to $38 \%$ at 28 days. Lightweight Concrete Research (BR) using additional polymers obtained significant results, at the age of 7 days, reaching $70 \%$ of the strength of the K 300 concrete plan. However, in the BR study using compressive strength polymers aged 14 and 28 days there was no significant increase of previous. At the age of 14 days only gained $74 \%$ and 28 days only gained $87 \%$ of the $\mathrm{K} 300$ strength. Effect of the addition of Polymer and Bonding on Concrete Compressive Strength, it was found that Lightweight Concrete with the addition of Polymer and Bonding had a slightly higher Compressive Strength of $2 \%$ than only the addition of Polymer.

\section{CONCLUSION}

Based on the analysis that has been done, some conclusions can be drawn as follows:

a. This study was able to obtain the optimum compressive strength results with light weight in the lightweight concrete research with the addition of Foam Agent, Polymer and Bonding with a quality of $267 \mathrm{~kg} / \mathrm{cm}^{2}$ or equivalent to Fc 22 with a weight of $1877 \mathrm{~kg} / \mathrm{cm}^{3}$ and an efficiency coefficient of $14 \%$ which higher than normal Concrete K 300 with a magnitude of $13 \%$.

b. The results of the lightweight concrete reaction using the addition of Polymer and Foam Agent obtained significant results, at the age of 7 days which reached $70 \%$ of the quality of $\mathrm{K} 300$ concrete, but at the age of 14 days only gained $74 \%$ and age of 28 days only gained $87 \%$ of the quality $300 \mathrm{~K}$.

c. The results of subsequent research reactions are Lightweight Concrete with the addition of Bonding, Polymer and Foam Agent (LC 3) an increase in quality by $2 \%$ from previous studies (LC 2 ) at the age of 28 days.

\section{REFERENCES}

ACI, 1995, Cement and Concrete Terminology (ACl SP-19), American Concrete Institute, Detriot Michigan.

Aji, Ir. MT. Dr. Techn Pujo., Purwono, Msc, Prof. Ir. IP-U HAKI Rachmat. 2010. "Pengendalian Mutu Beton sesuai SNI, ACI, ASTM". ITS Press. Surabaya.

Akbar, F, Ariyanto, A, dan Edison, B, (2013), Penggunaan Tempurung Kelapa Terhadap Kuat Tekan Beton K-100, Riau.FakultasTeknik Universitas Pasir Pengaraian.

ASTM Standards, 1985, Standar Specification for Portland Cement, ASTM C-150, ASTM International, USA.

ASTM Standards, 1995, Standar Defenition of Terminology Relating to Concrete and Concrete Aggregates, ASTM C-125, ASTM International, USA. 
ASTM Standards, 1995, Chemical Admixtures Concrete, ASTM C-494, ASTM International, USA.

ASTM Standards, 1982, Standar Specification for Concrete Aggregates, ASTM C-33, ASTM International, USA.

ASTM standards, 1995, Standar Specification for Coal Fly Ash and Raw or Calcined Natural Pozzolan for Use in Concrete, ASTM C-618, ASTM International, USA.

Danasi, M., (2014), PengaruhPenambahan Abu Terbang (Fly Ash) terhadap Kuat Tekan dan Modulus Elastisitas Beton Mutu Tinggi dengan Bahan Tambah Silica Fume, Superplasticizer, dan Filler Pasir Kuarsa, Skripsi. Universitas Atma Jaya. Yogyakarta.

Departemen Pekerjaan Umum. 1989. "Peraturan Beton 1989", (PB, 1989), Direktorat Penyelidikan Masalah Bangunan, Bandung.

Departemen Pekerjaan Umum. 1989. "Peraturan Beton 1989", (PB, 1989, SKBI 1.4.53.1989), Direktorat Penyelidikan Masalah Bangunan, Bandung.

Eniarti,M.,(2006), Pengaruh Pemanfaatan Serat Serabut Kelapa Terhadap Perbaikan Sifat Mekanik Beton Normal, Jurnal Spektrum Sipil,Volume 1, No.1: 19-20.

Kementerian Pekerjaan Umum dan Perumahan Rakyat. 2015. Pedoman Bahan Konstruksi Bangunan dan Rekayasa Sipil: Perencangan Campuran Material Ringan Mortar-Busa untuk Konstruksi Jalan.

Kementerian Pekerjaan Umum dan Perumahan Rakyat. 2015. Pedoman Bahan Konstruksi Bangunan dan Rekayasa Sipil: Spesifikasi Material Ringan Mortar Busa.

Kementerian Pekerjaan Umum dan Perumahan Rakyat. 2015. Pedoman Bahan Konstruksi Bangunan dan Rekayasa Sipil: Perencangan Timbunan Material Ringan Mortar-Busa untuk Konstruksi Jalan.

Kementerian Pekerjaan Umum dan Perumahan Rakyat. 2015. Pedoman Bahan Konstruksi Bangunan dan Rekayasa Sipil: Pelaksanaan Timbunan Material Ringan Mortar Busa.

Malau, F.B., (2014), Penelitian Kuat Tekan dan Berat Jenis Mortar untuk Dinding Panel Membandingkan Penggunaan Pasir Bangka dan Pasir Baturaja Dengan Tambahan Foaming Agent dan Silica Fume, Jurnal Teknik Sipil Dan Lingkungan. 2, (2), 287 296.

Muhaimin, Abdul. (2018). Pengaruh Penggunaan Additive Additon 5m Dengan Foam Agent Dan Serabut Kelapa Terhadap Beton. Universitas Narotama, Surabaya.

Mulyono, Tri. 2003. "Teknologi Beton". Andi. Yogyakarta.

Octavianto R, Vivaldi. (2018). Pengaruh Penambahan Polyvinyl Acetat Dan Batok Kelapa Pada Beton. Universitas Narotama, Surabaya.

Paramatatya, E., (2014), Pemanfaatan Endapan Kalsium Karbonat (CaCO3) Lokal Daerah "X" Sebagai Bahan Aditif Semen Pengeboran, Universitas Pembangunan Nasional Veteran, Yogyakarta. 
Purwono, Msc, Prof. Ir. Rachmat. 1997. "Peranan Beton dalam Industri Konstruksi”. FTSP-ITS. Surabaya.

Rochmah, N., (2016), Pemanfaatan Batu Kapur Di Daerah Sampang Madura Sebagai bahan Pengganti Agregat Kasar Pada Campuran Beton, JHP17: Jurnal Hasil Penelitian, Sep, 18;1(02).

Rustendi, I., (2004), Pengaruh Pemanfaatan Tempurung Kelapa Sebagai Material Serat Terhadap Kuat Tekan Dan Kuat Tarik Beton,Media Komunikasi Teknik Sipil, Vol. 12, No. 2, Edisi XXIX Juli 2004.

Sembiring, R.,(1998). Beton Mutu Tinggi dengan Mengganti Fraksi Halus Pasir Kali dengan Fraksi Halus Pasir Kuarsa terhadap Kuat Desaknya, Skripsi, Universitas Atma Jaya. Yogyakarta.

Simbolon dan Firmanto, E., (2015), Penggunaan Foaming Agent dalam Pembuatan Bata Beton Ringan, Disertasi Teknik Sipil USU Medan :Tidak diterbitkan.

Suarnita, I Wayan, (2010),Karakteristik Beton Ringan Dengan Menggunakan Tempurung Kelapa Sebagai Bahan Pengganti Agregat Kasar,Jurnal Smartek, Vol. 8, No. 1, Pebruari, hal 22-33.

Ulfa, M., (2006), Pengaruh Penambahan Serat Sabut Kelapa terhadap Kuat Tekan dan Kuat Lentur Beton,Skripsi, Universitas Andalas.

Widodo, S., (2003) et. al. Pemanfaatan Limbah Abu Batu sebagai Bahan Pengisi dalam Produksi Self Compacting Concrete.

Wijaya, D., dan Sumiyanto, (2013), Kajian Kuat Tekan Beton Dengan Kalsium Karbonat Sebagai Substitusi Sebagian Portland Cement. 